\title{
Classical Sāmkhya on the Authorship of the Vedas
}

\author{
Olena Lutsyshyna
}

Published online: 12 June 2012

(C) The Author(s) 2012. This article is published with open access at Springerlink.com

\begin{abstract}
The question as to whether the Vedas have an author is the topic of vivid polemics in Indian philosophy. The aim of this paper is to reconstruct the classical Sāmkhya view on the authorship of the Vedas. The research is based chiefly on the commentaries to the Sämkhyakārikā definition of authoritative verbal testimony given by the classical Sāmkhya writers, for these fragments provide the main evidence (both direct and indirect) for the reconstruction of this view. The textual analysis presented in this paper leads to the following conclusion. According to most classical Sāmkhya commentaries, the Vedas have no author. Two commentators state directly that the Vedas have no author, and four commentators allude to the authorlessness of the Vedas. Only one commentator seems to hold the opposite view, stating that all the authoritative utterances are based on perception or inference of imperceptible objects by authoritative persons, from which it follows that the Vedas too have an author or authors.
\end{abstract}

Keywords Classical Sāmkhya - Authoritative verbal testimony (āpta-vacana) . Authoritative persons (apta) · The Vedas · Authorless (apauruṣeya)

\section{Introduction: Purpose of this Paper, Its Limitations, and Primary Sources on Which it is Based}

Do the Vedas have an author? This may seem a strange question, for it is known from observations that texts arise thanks to the conscious efforts of their authors. But what about a text that never arose? According to Mīmāmsā, the authorless Vedas have no beginning, they have always been. Or what about a text that only

\footnotetext{
O. Lutsyshyna $(\bowtie)$

The University of Humanities and Economics in Lodz, ul. Lubeckiego 12, m. 2,

91-403 Łódź, Poland

e-mail: o_lutsyshyna@yahoo.co.uk; olutsyshyna@ahe.lodz.pl
} 
re-arises at the beginning of a new cycle of the existence of the world? Some philosophers, for example, Śankara and the followers of his Advaita, Bhartrhari the Grammarian and his followers, and probably Sāmkhyas accepted the conception of a periodic re-manifestation of the authorless Vedas. The question as to whether the Vedas have an author was a subject of vivid discussions in Indian philosophy. The main participants of these discussions were Mīmāmsā, for which the authorlessness of the Vedas was an argument for their unquestionable authoritativeness, and its rival Nyāya-Vaiśeșika, which held that no text can be without an author and based authoritativeness of the Vedas on the authority of their authors/author. The earlier Naiyāyikas attributed the authorship of the Vedas to the primeval seers endowed with the extraordinary power of direct cognition (perception) of unseen reality (see the Nyāyasūtras I, 1, 7-8; II, 1, 68 together with the Nyāyabhāşya), and the later Vaiśeșikas and Naiyāyikas attributed it to God (İ́sara). ${ }^{1}$

What is the view of Sāmkhya on the authorship of the Vedas? As regards the textual tradition of the classical and postclassical Sāmkhya, the earliest discussion of the issue of the authorship of the Vedas appears in the postclassical Sāmkhyasūtras (ca. 1400-1500 CE) ${ }^{2}$ and Aniruddha's Sāmkhyasūtravrtti (ca. 1400-1500 CE), where the Sūtrakāra and Aniruddha argue for the conception of the noneternal and authorless Vedas (see Sāmkhyasūtras and Sāmkhyasūtravṛtti V, 4550). The authors of the classical Sāmkhya do not focus attention on the question of the authorship of the Vedas. Most of them even do not express their standpoint directly. Only two classical Sāmkhya writers, namely, the author of the Yuktidīpikā and Vācaspati Miśra in his Sāmkhyatattvakaumud̄̄, formulate their standpoint explicitly, but neither of them gives any arguments in its favour. According to both of them, the Vedas have no author. Besides this direct evidence, texts of the classical Sāmkhya contain implicit evidence. The aim of this paper is to reconstruct the classical Sāmkhya view on the authorship of the Vedas on the basis of both direct and indirect evidence presented in its texts.

\footnotetext{
1 The conception of İśvara as an author of the Vedas is not present in earlier Nyāya works, such as the Nyāyasūtras, Vātsyāyana's (450-500 CE) Nyāyabhāṣya and Uddyotakara's (550-610 CE) Nyāyavārttika. This conception is distinctly formulated in the Nyāyamañjari of Jayanta Bhatta (840-900 CE) (Nyāyamañjarī. Summary prepared by K.H. Potter, J.V. Bhattacharya, and U. Arya. In: Potter 1977, pp. 371, 377-378). As regards early Vaiśeșika, this conception is not found in the Vaiśeșikasütras. It is stated in the Vaiśeșikasūtravṛtti of Candrānanda (the eighth or the ninth century CE), which is probably the oldest surviving commentary on the Vaiśeșikasutras. According to this commentary, the Vedas has been uttered by Maheśvara (see Bronkhorst 1996, p. 288). The conception of İ́vara as an author of the Vedas has become an established view of Nyāya and Vaiśeșika, presented in many texts, for example, Vyomavatī of Vyomaśiva (900-960 CE) (Vyomavatī. Summary prepared by V. Varadachari. In: Potter 1977, pp. 429, 447), Nyāyavārttikatātparyațīkā (see II, 1, 68) of Vācaspati Miśra (900-980 CE), Átmatattvaviveka (Ätmatattvaviveka. Summary prepared by V. Varadachari. In: Potter 1977, pp. 555-556), Nyāyakusumāñjali (Nyāyakusumāñjali. Summary prepared by K.H. Potter and J.V. Bhattacharya. In: Potter 1977, pp. 569, 588) of Udayana (1050-1100 CE), and Tarka-saingraha and Tarka-dīpikā (see 62) of Annambhatța (the seventeenth century CE). For the dates of Candrānanda and Annambhatta I consulted Matilal (1977, pp. 74-75, 107). For the dates of all the other writers of Nyāya and Vaiśeșika mentioned in this paper see Potter (1977, pp. 9-12).

2 The dates of all the Sāmkhya and Yoga texts mentioned in this paper are given according to Larson and Bhattacharya (1987, pp. 15-18, 19-22).
} 
It is necessary to point out the limitations of this research. This paper is based chiefly on those fragments of the classical Sāmkhya commentaries where the Sāmkhya writers explain the 'definition' of authoritative verbal testimony (âptavacana) given in the Sāmkhyakārikā (SK). Sāmkhya accepted three pramānas: perception (drșta), inference (anumāna), and authoritative verbal testimony (âptavacana, literally, 'authoritative utterance')—see kārikās 4-6 where Īśvarakṛ̣ṇa presents the Sāmkhya teaching on the sources of valid knowledge (pramāna). The commentaries to the SK 'definition' of äpta-vacana (Íśvarakrșna 'defines' it as äptaśruti- "authoritative śruti"; ${ }^{3}$ see SK 5) contain the main evidence (both direct and indirect) for reconstruction of the Sāmkhya view on the authorship of the Vedas. All the Sāmkhya writers interpreting this 'definition' tried to establish sources of authoritative utterances, i.e. valid sentences being the cause of valid knowledge which is called authoritative verbal testimony. The Vedas were considered to be the main source of authoritative utterances. Besides the commentaries to the definition of authoritative verbal testimony, the direct evidence presented in TK 2 has been considered. Thus all the direct evidence contained in the classical Sāmkhya texts, which is scarce (we find it in the three fragments: YD 5, TK 5, and TK 2), seems to have been taken into account.

The SK provides no evidence for reconstruction of the view on the authorship of the Vedas, so we concentrate on the SK commentaries, particularly on their definitions of authoritative verbal testimony (i.e. their interpretations of the SK definition of aptavacana). I shall cite these definitions or their parts containing the material for our analysis. I shall not provide a comprehensive analysis of these definitions; only those aspects will be considered which are important for clarifying the view on the authorship of the Vedas.

This study is based on all the eight extant commentaries of the classical Sāmkhya. These are the following commentaries on Ī́śvarakṛ̣ṇa's SK (ca. 350-450 $\mathrm{CE}$ ), listed in chronological order: the commentary surviving in the Chinese translation of Paramārtha ${ }^{4}$ (P; composed ca. $500 \mathrm{CE}$; translated into Chinese by Paramārtha between $557 \mathrm{CE}$ and $569 \mathrm{CE}$ ), Sāmkhyavrtti (SVṛ; ca. 500-600 CE), Sāmkhyasaptativrtti (SSVṛ; ca. 500-600 CE), Sāmkhyakārikābhāṣya (or Gauḍapādabhāṣya; GB; ca. 500-600 CE) by Gauḍapāda, Yuktidīpikā (YD; ca. 600-700 CE), Jayamaingalā (JM; ca. $700 \mathrm{CE}$ or later), Mătharavṛtti (MV; ca. $800 \mathrm{CE}$ or later) by Māthara, and Sāmkhyatattvakaumudī (TK; ca. 841 CE or ca. 976 CE) by Vācaspati Miśra. By classical Sāmkhya I mean Sāmkhya presented in the SK and the abovementioned eight commentaries. After the TK the long period of stagnation in the development of Sāmkhya begins, which ends in the XIV century with the appearance of the new (postclassical) form of Sāmkhya presented in the Tattvasamāsasūtra (ca. 1300-1400 CE) and its commentary Kramadīpikā (ca. 1300-1400 CE).

\footnotetext{
3 It is difficult not to agree with Solomon who notes that "āptaśruti can hardly be called a definition" (Notes. In Sāmkhya-Vṛtti (V2), 1973, p. 78).

4 The Sanskrit original of this text has been lost. I do not know Chinese and rely on the French translation of Takakusu (La Sāmkhyakārikā étudiée à la lumière de sa version chinoise, 1904) and the reconstruction into Sanskrit prepared by N. Aiyaswami Sastri (Suvarṇasaptati Śāstra, 1944).
} 


\section{The Commentary Translated into Chinese by Paramārtha}

This is the definition of authoritative verbal testimony given in this commentary, together with the version of the SK definition we find here. Translation of P 5 from Takakusu (La Sāmkhyakārikā étudiée à la lumière de sa version chinoise, 1904):

A teaching of a saintly person is called sacred authority. ${ }^{5}$

... A teaching of a saintly person etc. For example, the four Vedas uttered by the god Brahmā and the Dharmaśāstra of the king Manu. ${ }^{6}$

Translation of P 5 from the Sanskrit reconstruction of N. Aiyaswami Sastri (Suvarnasaptati Śāstra, 1944):

The word of authority (āpta-śruti) is called authoritative verbal testimony (äpta-vacana).

The word of authority is called authoritative verbal testimony-for example (yathā), ${ }^{7}$ that what is uttered by Brahmā and by Manu, that is, the four Vedas and the Treatise on Dharma (dharma-śāstra). ${ }^{8}$

According to this commentary, authoritative verbal testimony is the word of an authoritative person. So, authoritative statements are the statements uttered by authoritative persons. The sources of authoritative statements include the Vedas uttered by the god Brahmā and the Treatise on Dharma uttered by Manu. Manu is Manu Svayambhuva ('self-existent'), the first Manu of our kalpa, ${ }^{9}$ to whom the Hindu tradition ascribes Manusmrti (also called Mānavadharmaśāstra or Manusamitia ), the most authoritative of the dharmaśästras, treatises on dharma. He is the son of Brahmā. By the Treatise on Dharma (dharmaśāstra used in singular number) Manu-smrti is probably meant. In P all the authoritative statements are associated with certain authoritative persons, but it is not said whether these persons are the authors of these statements. The Vedas too are associated with the certain person, i.e. the god Brahmā who uttered them, but it is not clear if the god Brahmā is the author of the Vedas.

\footnotetext{
5 I use italics to distinguish the text of the kārikā.

6 Takakusu's French translation:

L'enseignement d'un saint personnage est appelé autorité sacrée.

(...) L'enseignement d'un saint personage, etc. Par exemple les quatre Védas énoncés par le dieu Brahmā et la Dharmaśāstra du roi Manu.
}

It is necessary to note that there is an English translation from Takakusu's rendering, prepared by S.S. Suryanarayanan, who is known also as S.S. Suryanarayana Sastri (The Sāmkhya Kārikā Studied in the Light of Its Chinese Version, 1932, 1933), and my translation is very similar to it.

7 Yathā can be also translated as 'namely'.

8 äpta-śrutir äpta-vacanam ucyate \|

... āpta-śrutir āpta-vacanam ucyate iti | yathā brahmaṇā manunā ca uktāś catvāro vedā dharmaśāstrañ ca\|

${ }^{9}$ Kalpa is the day of Brahmā in Hindu cosmology. After it the night of Brahmā comes, i.e. the dissolution (pralaya) of the created world, after which the next day of Brahmā begins. Every kalpa consists of 14 manvantaras, and every manvantara ('the age of a Manu') has its own Manu, its own seven great seers, its own Indra and other gods. 


\section{The Sämkhyavrtti and the Sämkhyasaptativṛtti}

The definitions of authoritative verbal testimony given in these commentaries are very similar. The definition of the $\mathrm{SVr}$ (5) is as follows:

This is the definition (lakșana) of authoritative verbal testimony (āpta-vacana). It is said here [i.e. in the SK]: "The revelation of authorities (āpta-śruti) and the word of authorities (āpta-vacana) [constitute äpta-vacana-authoritative verbal testimony]". Here the name 'āpta' [is applied to] the teachers (ācārya): Hari, Hara, Hiranyagarbha, etc. The 'revelation' (śruti) of these authorities is the Vedas. That is the meaning [of aptaśruti being the first part of the definition of authoritative verbal testimony]. The 'authorities' (apta) which are the authors (kāra) of the treatises on dharma (dharma-śāstra) are Manu, etc., [and] 'the word of authorities' (apta-vacana) is 'the word' (vacana) of these authorities-that [is the meaning of aptavacana being the second part of the definition of authoritative verbal testimony]. ${ }^{10}$

The definition we find in the SSVr 5 is practically the same:

"What is the definition (laksana) of authoritative verbal testimony?" On this account it is said [in the SK]: "The revelation of authorities (apta-śruti) [and] the word of authorities (âpta-vacana) [constitute âpta-vacana-authoritative verbal testimony]". There the name 'apta' [is applied to] Hari, Hara, Hiranyagarbha, etc. 'The revelation of authorities' (apta-śruti) is the 'revelation' (śruti) of these 'authorities' (apta). The 'revelation of authorities' (apta-śruti) is the Vedas. That is the meaning [of aptaśruti being the first part of the definition of authoritative verbal testimony]. 'Authorities' (apta) are the authors (kartr) of the treatises on dharma (dharma-śāstra): Manu, etc., [and] 'the word of authorities' (apta-vacana) is 'the word' (vacana) of these authorities - that [is the meaning of aptavacana being the second part of the definition of authoritative verbal testimony]. ${ }^{11}$

In the SVrr and SSVṛ āptaśruti and aptavacana are interpreted as the two parts of the definition of aptavacana. This reading seems to contradict the intention of the author of the SK. It is clear from kārikā 4 that Íśvarakṛ̣ṇa treats āptavacana as the defined notion (definiendum), and not as the defining expression (definiens). In kārikā 4 Íśvarakṛṣna introduces the sources of valid knowledge to be defined in kārikā 5, and one of them is aptavacana.

According to the SVr and SSVr, authoritative verbal testimony is "the revelation of authorities (apta-śruti) and the word of authorities (apta-vacana)". The revelation

\footnotetext{
${ }^{10}$ äpta-vacanasya lakșaṇam iti | atrôcyate āpta-śrutir āpta-vacanam ca | atra āptā nāmâcāryāh harihara-hiranyagarbhâdayaḥ teșām āptānām śrutih veda ity arthah | manv-ādayo dharma-śāstra-kārāh $\bar{a}$ tāh teșām āptānām vacanam āpta-vacanam iti |

The Sanskrit text of the SVr and SSVr is given by me together with the editor's corrections and insertions of E. Solomon and without marking these emendations.

11 āpta-vacanasya kim lakṣaṇam ity atrôcyate āpta-śrutir āpta-vacanam | tatra āptā nāma hari-harahiranyagarbhâdayas teșāim āptānām śrutir āpta-śrutiḥ $\mid \bar{a} p t a-s ́ r u t i r$ veda ity arthah $\mid$ manv-ādayo dharmaśāstrāṇām karttāra āptās teșām āptānām vacanam āpta-vacanam iti ।
} 
of authorities is the Vedas, which is the revelation of such authorities as Hari, Hara, and Hiranyagarbha. The word of authorities is dharmaśāstras, composed by Manu and other authorities. In the SVr and SSVr, as in P, all the authoritative statements are associated with certain authoritative persons. Hari, Hara, and Hiranyagarbha ('a golden embryo') are the epithets respectively of Viṣnu, Śiva, and Brahmā, the main Hindu gods, which were often understood as the three aspects of one divine being from which the universe and the Vedas originate. Did these gods (1) compose (create) the Vedas (being their authors), (2) discover them, (3) remember them from the previous cycle of the existence of the world, ${ }^{12}$ or (4) give them out spontaneously? In the SVrr and SSVr we do not find a direct answer to this question. None of these possibilities can be excluded.

As regards the last possibility, in the SVr and SSVr the Vedas could be comprehended as issuing spontaneously from the mouths of Hari, Hara, and Hiranyagarbha or from one divine being of which these gods are the forms. Such a view on the origin of the Vedas could also be peculiar to the P: we cannot exclude that in the $\mathrm{P}$ the Vedas were understood as issuing spontaneously from the mouth of Brahmā. According to the Bṛhadāranyakopanișad (see II, 4, 10), the Vedas go out of "the great being" (mahad bhütam) together with its breath. It is said here that the Vedas are breathed out (nihśvasita) by this being. Later this idea was developed by the famous Advaita Vedāntin Śankara (flourished at the beginning of the eighth century CE). ${ }^{13}$ Śankara says that the Vedas arise from Brahman spontaneouslylike a breath which issues from a man spontaneously, without any special, conscious effort. In his commentary to the Brahmasūtra, Śankara calls Brahman, being the source (yoni) of the Vedas, omniscient and omnipotent, from which it is clear that it is İ́vara, the subtlest manifest form of Brahman, by whom the Vedas are "breathed out" (see Śankara's Brahmasūtrabhāṣya I, 1, 3 and Bṛhadāraṇyakopanișadbhāṣya II, 4, 10). Unlike Advaita Vedānta, the classical Sāmkhya accepts neither the existence of God (Íśvara), nor the theory that from the "highest standpoint" (pāramārthika) Brahman is the true essence of everything and the only real existent. I suppose that in Sāmkhya the view that the Vedas spontaneously go out of Brahmā or other divine beings could have the following shape: the Vedas arise from prakrti (primordial creative matter) spontaneously, but prakrti "creates" them by the agency of the creator god Brahmā or other divinities which appear at the beginning of a new cycle of the existence of the world. It is worth noticing that according to the postclassical Sämkhyasūtras and Sämkhyasūtravrtti, which like the classical Sāmkhya deny the existence of God, ${ }^{14}$ the authorless Vedas evolve from prakrti spontaneously, though there is no mention of the role of Brahmā or like beings in these texts (see Sämkhyasūtras and Sāmkhyasūtravrtti V, 46-50).

In the SVr and SSVṛ definitions of authoritative verbal testimony cited above, we find the allusion that Hari, Hara, and Hiranyagarbha are not the authors of the Vedas.

\footnotetext{
${ }^{12}$ For the third possibility see below the analysis of the view on the authorship of the Vedas presented in the TK.

13 For the dates of Śankara see Potter (1981, p. 15).

14 In my article titled "Atheism in the Sāmkhyasūtras and the Sāmkhyasūtravrtti" (Łucyszyna 2011) I show that the Sämkhyasūtras and Sämkhyasütravrtti were clearly atheistic (i.e. refuting the existence of God) in their character.
} 
This indirect evidence consists of the following: distinguishing the authorities which uttered the Vedas from the authorities to which we owe dharmaśāstras, both commentators call the authors (kāra, kartr; in the SVr the commentator uses the word kāra, and in the SSVr- the word kartr) only those latter authorities.

\section{The Gaudapādabhāṣya and the Mätharavrtti}

According to both these commentaries, authoritative verbal testimony (äptavacana) embraces "authorities (āpta) [and] revelation (śruti)". GB 5:

[This is the definition of authoritative verbal testimony presented in the SK:] "And (ca) authoritative verbal testimony (äptavacana) is authorities (āpta) [and] revelation (śruti)". Authorities are the teachers (ācārya): Brahmā, etc. Revelation is the Vedas. Apta-śruti [embraces] both authorities (āpta) and revelation (śruti). Thus has been explained the authoritative verbal testimony. ${ }^{15}$

MV 5:

[This is the definition of authoritative verbal testimony presented in the SK:] "And (tu) authoritative verbal testimony (äptavacana) is authorities (āpta) [and] revelation (śruti)". This is the third source of valid knowledge. Authorities are the teachers ( $\bar{c} c \bar{a} r y a)$ : Brahmā, etc., [and] revelation is the Vedas - these are the two kinds of authoritative verbal testimony.... Thus has been explained the authoritative verbal testimony. ${ }^{16}$

Gauḍapāda and Māṭhara interpret āpta-śrutị̣ as authorities (āptāḥ) and revelation (śrutih). They apparently treat apta-śrutih as a dvandva compoundnotwithstanding the fact that in the SK this word is in the feminine singular, i.e. the form in which dvandva compounds do not occur (in our case if apta-śruti were a $d v a n d v a$ compound, it would have the plural form apta-śrutayah). Authorities include Brahmā and other teachers, and revelation is the Vedas. Unlike in the P, SVr, and SSVr, where all the authoritative utterances are associated with certain authoritative persons, in the GB and MV authorities and revelation represent two separate sources of authoritative utterances. In that way Gauḍapāda and Māṭhara probably wanted to say that the revelation (śruti), i.e. the Vedas, was not composed (created) by authoritative persons, that is, it does not have an author.

\section{The Yuktidīpikā and the Sāmkhyatattvakaumudī}

Both these commentaries, though very different, state directly that the Vedas have no author, treating the authorlessness of the Vedas as the argument for their

\footnotetext{
$\overline{15}$ āpta-śrutir āpta-vacanam ca $\mid \bar{a} p t \bar{a}$ ācāryā brahmâdayah $\mid$ śrutir vedah $\mid$ āptāś ca śrutiś ca āpta-śrutih tad uktam āpta-vacanam iti $\mid$

16 āpta-śrutir āpta-vacanam tu | tritīyam pramāṇam | āptā brahmâdaya ācāryāh śrutir vedas tad etad ubhayam āpta-vacanam | ... tad uktam āpta-vacanam $\mid$
} 
unquestionable authoritativeness. Below I shall cite those fragments of the YD's and the TK's commentaries to the definition of authoritative verbal testimony which are relevant to the issue of the authorship of the Vedas. YD 5:

[It is said in the SK:] "Authoritative verbal testimony (apta-vacana) is authoritative revelation (āpta-śruti) [and the word of authorities (āpta-śruti)] only (tu)".

... Śruti is the revelation (śravana). Authoritative revelation (āpta-śruti) is that revelation (śrutih) which is authoritative $(\bar{a} p t \bar{a})$. Or thus [is the meaning of the compound apta-śruti]. ... Apta-śruti is the word (śruti) [that comes] from authorities (apta). Apta-śruti is both the authoritative revelation (apta-śruti) and the word of authorities (apta-śruti). [According to the grammatical rule which sounds:] "out of [two or more words] having the same form...", [out of two similar words āpta-śruti and apta-śruti] one [only] remains (eka-śeșa). ${ }^{17}$ There through mentioning the first apta-śruti the following is maintained: the Vedas (āmnāya) not created by the intellect of [some] purușa ${ }^{18}$ (a-purușabuddhi-pürvaka), which are independent (svatantra) and inducing to the highest aim of a human, are the source of valid knowledge that cannot be doubted. Through the second [apta-śruti] it is established that the word (vacas) of the smrtis ${ }^{19}$ composed by Manu, etc., of the Vedāngas, treatises on logic (tarka), Itihāsas, Purānas, and of the learned persons versed in various arts, which are not faulty-minded, is the source of valid knowledge. ${ }^{20}$

According to the YD, authoritative verbal testimony (apta-vacana) embraces authoritative revelation (āpta-śruti) and the word of authorities (āpta-śruti). In order to ground his interpretation of the SK definition of authoritative verbal testimony, the author of the YD employs the linguistic trick, treating aptaśrutih as eka-śeșa (literally, 'one [only] remaining [of two or more stems]', see footnote 17) which stands for the two words: apptaśrutih and aptaśrutih, i.e. 'authoritative revelation'

\footnotetext{
17 The author of the YD refers to the grammatical rule formulated in sūtra I, 2, 64 of the Aștāadhyāyz of Pānini. The sūtra is the following: "Out of [two or more words] having the same form one [only] remains (eka-śeșa), if they have the same inflexion" (sarūpānām eka-śeșa eka-vibhaktau \| The Aștādhyāȳ of Pānini 2000: 133-134). According to this rule, if two or more similar words which have the same ending (these are the words that can be joined by the copulative conjunction 'and') occur, only one of these words remains. The word that remains has its own meaning and the meaning of the omitted word (or words). The grammatical form of the remaining word will be dual or plural (depending on that how many things it stands for).

18 By puruṣa the author means a being which is animated by puruṣa (ātman) that makes this being conscious.

19 In this context the word smrti, which occurs here in the plural form (smritīnām), means dharmaśāstras.

${ }^{20}$ äpta-śrutir äpta-vacanaì tu $\|$

... śravanam śrutiḥ | āptā câsau śrutiś ca āpta-śrutih | athavā ... | āptebhyah śrutir āpta-śrutir | āpta-śrutiś câpta-śrutiś câpta-śrutih | sarūpāṇām ity eka-śeșah | tatra pūrvenâpta-śruti-grahanenêdam pratipādayati | apurușa-buddhi-pūrvaka āmnāyah sva-tantrah puruṣa-nihśreyasârtham pravartamāno nihsamśayam pramāṇam iti $\mid$ dvitīyena manv-ādi-nibandhānāim ca smrtīnām vedānga-tarkêtihāsa-purānānāà śiștānāàm nānā-śilpâbhiyuktānāim câdușta-manasāim yad vacas tat pramānam ity etat siddham bhavati | (Yuktidīpikā 1998, p. 87, v. 1-12.) The YD gives more extensive explanations of most of the kārikās than other commentaries of the classical Sāmkhya, that is why in my references to the YD, besides the number of the kārikā, I indicate the page and the verse number of the edition of the YD.
} 
and 'the word of authorities'. Aptaśrutih occurring in the SK cannot be interpreted as $e k a$-śesa-for the reason that it is used in the singular form. If it were eka-śesa meaning 'āpta-śruti and āpta-śruti', it would have the dual form apta-śrutī. However, the interpretation of apta-śrutih as both authoritative revelation and the word of authorities is not impossible, for we cannot exclude that in the SK the word $\bar{a}$ ta-śruti is used in a double sense.

It is easy to notice the following similarity between the YD and the two commentaries we analyzed above. In the YD, like in the GB and MV, authoritative utterances originate from authorities and from the revelation (i.e. the Vedas) which is not associated with any authorities. Treating authoritative revelation and the word of authoritative persons as two separate sources of authoritative utterances, the author of the YD distinguishes in that way the utterances composed by certain authors from the utterances of the authorless Vedas. Moreover, the YD presents the direct evidence in the question of the authorship of the Vedas: the Vedas are said to be "not created by the intellect of [some] puruṣa" (a-puruṣa-buddhi-pūrvaka), i.e. by the intellect of some conscious being. It means that the Vedas have no author.

So, in the YD it is asserted directly that the Vedas have no author. It is very likely that in the YD, like in Mīmāmsā, the authorlessness of the Vedas represents the argument for their unquestionable authoritativeness. In the same sentence of the YD where the Vedas are said to be without an author we find also other characteristics applied to the Vedas by the Mīmāmsakas, namely, their being independent (svatantra), their being "inducing to the highest aim of a human" (purușanihśreyasârtham pravartamānah), and their possessing the validity that even cannot be doubted. By the independence of the Vedas both in Mīmāmsā and Sāmkhya there can be understood, first, their independence from any author, second, independence of their scope, or functional sphere, that also means their independence from other sources of valid knowledge. These two independences-independence from any author and independence of the scope_represent in Mīmāmsā two main arguments for the unquestionable authoritativeness of the Vedas. Calling the Vedas "the source of valid knowledge that cannot be doubted" (nihsamśayam pramānam), the author of the YD asserts this unquestionable authoritativeness of the Vedas. According to Mīmāmsā, validity of the Vedic utterances can never be doubted for the following reasons: first, they have no author that can speak untruth, second, they can never be refuted because of the independence of their scope (in other words, they are unfalsifiable by other pramānas, for imperceptible things which constitute the domain of authoritative verbal testimony are incognizable by other pramānas)—see Śabara's (350-400 CE) ${ }^{21}$ Śäbarabhāşya I, 1, 2; I, 1, 5. Taking into account the fact that the context of the fragment of the YD where the Vedas are said to be without an author is influenced by Mīmāmsā, and the fact that the authorlessness of the Vedas is connected with their undoubtable reliability, we can conclude that it is very likely that in the YD, like in Mīmāmsāa the authorlessness of the Vedas is regarded as an argument for their unquestionable authoritativeness.

The commentary to the definition of authoritative verbal testimony given in TK 5 is also influenced by Mīmāmsā. I shall now cite the relevant passage of this commentary:

\footnotetext{
21 The dates of Śabara are given according to Verpoorten (1987, pp. 8-9).
} 
... And that [cognition through authoritative verbal testimony] is intrinsically valid (svatah-pramāna). It is true (yukta), because it is entirely free from suspicion of [any] defectiveness inasmuch as it is born by sentences of the authorless (apauruseya) Vedas. Thus the cognition born by sentences of the smrtis, ${ }^{22}$ Itihāsas, and Purānas, which are rooted in the Vedas (veda-mūla), is also true (yukta). And the primeval sage Kapila at the beginning of the kalpa remembers śruti studied [by him] during the [previous] kalpa(s)... ${ }^{23}$

Vācaspati Miśra states directly that the Vedas have no author-by calling them apauruseya, which means literally "not coming from purusa". The authorlessness of the Vedas is used here, like in Mīmāmsā, as the argument for their unquestionable authoritativeness. No doubt is possible about knowledge generated by sentences of the Vedas-for they have no author whose reliability can be doubted. A doubt about the validity of Vedic sentences cannot arise-for there is no reason for it. It is obvious that Vācaspati's commentary is influenced by Mīmāmsā. In the small fragment cited above we find the following ideas which were systematically developed in Mīmāmsā: the idea of intrinsic validity of cognition through authoritative verbal testimony; the idea of the authorlessness of the Vedas regarded as the argument for their unquestionable authoritativeness; the idea that authoritativeness of those texts which have an author lies in their being based on the Vedas.

In the TK there is one more instance of direct evidence in the question of the authorship of the Vedas. In TK 2 Vācaspati says that the Vedas are only transmitted from teacher to pupil, "but they are not created by anybody" (na tu kenacit kriyate). Vācaspati states here directly that the Vedas have no author. In that fragment also we see the influence of Mīmāmsā which claims that the Vedas were not created by some author, human or divine, but came to us through unbroken tradition of the Vedic recitation.

But how is it possible to fit this Mīmāmsā view on the Vedas in the doctrine of Sāmkhya which, unlike Mīmāmsā, accepts the conception of periodic dissolutions (pralaya) of the world? How is it possible to introduce the idea of the unbroken tradition of the Vedic recitation into the Sāmkhya cosmological framework? According to Mīmāmsā, both the Vedas and the world have no beginning in time. They have always been. They never arose. The present-day Vedic teachers have heard the Vedas from their teachers, and their teachers also had teachers from whom they learned the Vedas, and so on-without beginning. According to Sāmkhya, all the world, except purușa and prakrti which are eternal, undergo destruction (i.e. dissolution in prakrti) during pralaya, emerging from prakrti again at the beginning of a new kalpa. The Vedas also undergo dissolution during pralaya, and the tradition of their recitation breaks.

\footnotetext{
22 By smṛtis Vācaspati means dharmaśāstras.

23 ... tac ca svatah-pramāṇam apaurușeya-veda-vākya-janitatvena sakala-doṣâsañkā-vinirmuktatvena yuktam bhavati evai் veda-mūla-smṛtîtihāsa-purāṇa-vākya-janitam api jūānam yuktam ādi-viduṣaś ca kapilasya kalpâdau kalpântarâdhīta-śruti-smaraṇa-sambhavah ....
} 
Vācaspati Miśra seems to be aware of the difficulties of fitting the Mīmāmsā view on the Vedas into the Sāmkhya doctrine. How does he solve these difficulties? We can reconstruct his solution on the basis of the following passage: "And the primeval sage Kapila at the beginning of the kalpa remembers śruti studied [by him] during the [previous] kalpa(s)..." (see TK 5 cited above). By saying that Kapila at the beginning of the kalpa remembers the Vedas studied by him before the time of dissolution (pralaya), Vācaspati tries to preserve the continuity of the Vedic recitation before and after pralaya. From this passage it is clear that the Vedas of the new cycle of the existence of the world are similar to the Vedas before pralaya, and that there are persons (or a person, namely, Kapila, who is identified by Sāmkhya as its founder) with extraordinary capacities who are able to remember the Vedas studied before pralaya and, in that way, to recommence the tradition of the Vedic recitation interrupted by pralaya.

\section{The Jayamangalā}

The JM stands out against the background of most Sāmkhya texts (i.e. the texts containing suggestions or direct statements that the Vedas are without an author), for it follows from its commentary to the definition of authoritative verbal testimony that the Vedas have an author or authors. Below I shall cite the relevant fragment of this commentary. JM 5:

"And (ca) authoritative verbal testimony is the word of authority"- thus [it is said in the SK]... That word (śruti) which came [to us] from authoritative persons ( $\bar{a} p t a)$ through the uninterrupted learned tradition (śruti-paramparāa) is [called] authoritative verbal testimony. An object which has been perceived or inferred by them [i.e. by authoritative persons] is presented (upadiśyate) to another [person] by means of words - in order to give rise in another [person] to [such a] knowledge (bodha) which is similar to [their] own knowledge. That [verbal testimony] which is authoritative verbal testimony does not shake (na plavate). ${ }^{24}$

Unlike most Sāmkhya commentators, the present commentator speaks only about one type of authoritative verbal testimony, namely, the word of authoritative persons. The author of the JM does not draw a distinction between Vedic utterances and other authoritative utterances. He holds that all the authoritative utterances are based on perception or inference of certain objects by trustworthy persons (according to Sāmkhya theory of the scope of the third pramanna these objects are the objects reachable neither by perception of ordinary people nor by inference which rests upon such a perception). It follows from this that the Vedic utterances also have an author or authors. It is not clear if the Vedas have one author (for example, Kapila) or many authors (for example, different rșis). It is not clear, also,

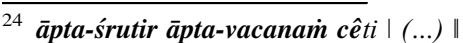

$\bar{a}$ tebhyo yā śruti-paramparayā śrutir āgatā tad āpta-vacanam tair dṛșto'numito vârthah paratra svabodha-sadrśa-bodhântarôtpattaye śabdenôpadiśyate | yad āpta-vacanam tan na plavate |
} 
whether the capacity of the direct cognition of unseen reality of this author/these authors is limited. It is said that authoritative persons base their reliable statements both on perception and inference, from which it follows that all of these authorities or some of them are not capable of perceiving all the objects. If perception of each authoritative person embraced all the objects, there would be no mention of acquiring knowledge by inference. It is not specified in the JM if all the authorities obtain knowledge by inference also or it refers only to those authorities which are not the authors of the Vedas; so it is not clear whether the authority/authorities which composed the Vedas based their trustworthy utterances not only on perception but also on inference.

It is difficult not to notice a close resemblance between the above-cited definition of authoritative verbal testimony of the JM and the definition of the Yogas $\bar{u}$ trabhāsya (ca. 500-700 CE (?)), given in its commentary on sūtra I, 1, 7 of the Yogasütra (though the author of the JM uses for authoritative verbal testimony the Sāmkhya term āpta-vacana and not the Yogic term āgama we find in the Yogasūtrabhāsya). ${ }^{25}$ I would like to emphasize that the above-cited fragment of the JM was interpreted in the context of the JM and Sāmkhya (and not in the context of Yoga). Unlike Sāmkhya (see kārikā 6 of the SK and the commentaries to this kārikā), Yoga (see such texts as Yogasūtras, Yogasūtrabhāṣya, Tattvavaiśārad̄̄ (ca. $841 \mathrm{CE}$ or ca. $976 \mathrm{CE}$ ) of Vācaspati Miśra, and Rājamārtaṇda (ca. $1150 \mathrm{CE}$ ) by Bhoja Rāja) does not state that authoritative verbal testimony has independent scope including only those things which cannot be validly cognized by perception or inference of ordinary people (i.e. people not endowed with an extraordinary capacity of perception of imperceptible reality). Hence, in Yoga authoritative verbal testimony is a source of valid knowledge of those things also which are reachable by perception and inference of ordinary people, and inference mentioned in the definition of àgama given in the Yogasūtrabhāsya is probably a means of cognition of those authorities which are ordinary people (and not of those authorities which are capable of direct cognition of unseen reality). It follows from this that in the context of Yoga (unlike in the context of Sāmkhya) this mention about an inferential cognition of authoritative persons does not necessarily lead to the conclusion that all or some of the authorities which communicate about imperceptible reality cognize this reality not only by means of perception but also by means of inference.

${ }^{25}$ Cf. Yogasūtrabhāṣya I, 1, 7:

āptena drșțo'numito vârthah paratra sva-bodha-samkrāntaye śabdenôpadiśyate śabdāt tad-arthavișayā vrttih śrotur āgamaḥ | yasyâśraddheyârtho vaktā na dṛștânumitârthaḥ sa àgamah plavate | mūla-vaktari tu drșțânumitârthe nirviplavaḥ syāt \|

An object which has been perceived or inferred by authoritative person ( $\bar{a} p t a$ ) is presented (upadiśyate) by means of words - in order to transmit [his] own knowledge (bodha) to another [person]. Authoritative verbal testimony (āgama) is [such] a process (vrtti) [taking place in the mind] of the hearer [which has been engendered] by [authoritative] word [and] has as [its] object the meaning of that [word]. If a speaker [communicates] about an unbelievable object [or] an object which has not been perceived or inferred, such authoritative verbal testimony (āgama) shakes (plavate). But if the original speaker has [himself] perceived or inferred the object, [such authoritative verbal testimony] will be indestructible. 


\section{Conclusion and Perspectives for Future Research}

The aim of this paper was to reconstruct the classical Sāmkhya view on the authorship of the Vedas. The research was based on the commentaries to the SK definition of authoritative verbal testimony (given in kārikā 5) which contain the main evidence (both direct and indirect) for reconstruction of this view. Besides the fragments where the classical Sāmkhya writers explain the SK definition of authoritative verbal testimony, the fragment of TK 2 containing the direct evidence in the question of the authorship of the Vedas was considered. In that way all the direct evidence I had found in the texts of classical Sāmkhya (it seems not to be numerous, formulated three times only-in YD 5, TK 5, and TK 2) was taken into account.

The analysis presented in this article leads to the following conclusion. According to most classical Sāmkhya commentaries, the Vedas have no author. Such conclusion is supported by all the direct evidence we find in the classical Sāmkhya texts and by indirect evidence given in five classical Sāmkhya commentaries to the definition of authoritative verbal testimony. In YD 5, TK 5, and TK 2 the Sāmkhya writers state directly that the Vedas have no author. The fragments containing the direct evidence are influenced by Mīmāmsā. Vācaspati Miśra in the TK, trying to fit the Mīmāmsā idea of the uninterrupted tradition of recitation of the authorless Vedas in the doctrine of Sāmkhya which accepts the conception of periodic dissolutions (pralaya) of the world, suggests, first, that the Vedas after pralaya are similar to the Vedas before pralaya, second, that there are persons (or a person, i.e. Kapila) capable of remembering the Vedas existing before pralaya and recommencing in that way the tradition of their recitation interrupted by pralaya. As regards the indirect evidence, it is as follows: first, in SVṛ 5 and SSVṛ 5 the commentators, distinguishing between authorities who uttered the Vedas and authorities to whom we owe dharmaśāstras, call the authors (kāra, kārtr) only the latter authorities; second, in GB 5, MV 5, and YD 5 utterances of authoritative persons and utterances of the Vedas, which are not associated with any authorities, represent two separate types of authoritative utterances.

The only commentary which seems to suggest that the Vedas have an author (or authors) is the JM. According to the JM definition of authoritative verbal testimony, which is influenced by Yoga, all the authoritative utterances are based on perception or inference of certain objects by authoritative persons (see JM 5). It follows from this that the Vedas too have an author or authors.

Future research perspectives include, first of all, clearing up whether the classical Sāmkhya texts contain other indirect evidence in the question of the authorship of the Vedas. In order to clear it up we should examine carefully all the fragments where there are mentions of the Vedas, authoritative utterances, Kapila, rșis, and the like persons. After that we should study pre-İ́sarakṛ̣ṇa Sāmkhya material and postclassical Sāmkhya texts, as well as external evidence, i.e. the evidence presented in the texts which do not belong to Sāmkhya tradition. 
Open Access This article is distributed under the terms of the Creative Commons Attribution License which permits any use, distribution, and reproduction in any medium, provided the original author(s) and the source are credited.

\section{References and Abbreviations}

\section{Sāmkhya Texts and Abbreviations}

GB. Sāmkhyakārikābhāṣya, or Gauḍāādabhāṣya = The Sānkhya Kārikā with an Exposition Called Candrikā by Nārāyaṇa Tìrtha, and Gaudapādācārya's Commentary (1883). Edited by Becanarāma Tripāthī. Benares: Messrs. Braj B. Das \& Co. (Benares Sanskrit Series. No. 9.).

JM. Jayamañgalā = Sāmkhyakārikā of Śrīmad İ́sarakrș̣na with the Mātharavrttti of Mātharācārya and the Jayamañgalā of Śrī Śankkara (1970). Edited by Vișṇuprasāda Śarmā [MV] and Satkāriśarmā Vangīya [JM]. Varanasi: Chowkhamba Sanskrit Series Office. (Chowkhamba Sanskrit Series. No. 56.)

MV. Mātharavrtti-see above JM. Jayamañgalā.

P. The Commentary translated into Chinese by Paramārtha = (1) La Sāmkhyakārikā étudiée à la lumière de sa version chinoise (II). Traité sur les «Septante d'or» (Suvarnasaptati) ou Traité sur la philosophie Sāmkhya (Sāmkhyaśāstra) traduit par Paramārtha (1904). Traduit de chinois par Junjiro Takakusu. Bulletin de l'Ecole Française d'Extrême-Orient 4, 978-1064. (2) Suvarnasaptati Śāstra. Sānkhya-Kārikā-Saptati of Íśvara-Kṛṣna with a Commentary (1944). Reconstructed into Sanskrit from the Chinese Translation of Paramārtha and Edited with English Notes, Introduction and Appendices by N. Aiyaswami Sastri. Tirupati: Tirümalai-Tirupati Devasthanams Press. (Sri Venkatesvara Oriental Series 7.) (3) The Sāmkhya Kārikā Studied in the Light of Its Chinese Version (1932, 1933). Translated [from the French translation of Takakusu] by S.S. Suryanarayanan [known also as S.S. Suryanarayana Sastri]. Journal of the Madras University 4(Supplement); 5, 81-114.

Sämkhyasūtras and Sāmkhyasütravrtti = Aniruddha's Commentary and the Original Parts of the Vedāntin Mahādeva's Commentary to the Sāmkhya Sūtras (1888). Edited with Indices by R. Garbe. Calcutta: Asiatic Society of Bengal.

SK. Sāmkhyakārikā = Íśvarakrṣna: Sāmkhyakārikā (1998). Edited by Ferenc Ruzsa. http://gretil.sub.unigoettingen.de/gretil/1_sanskr/6_sastra/3_phil/samkhya/isvskaru.htm. Accessed 5 December 2011.

SSVr. Sämkhyasaptativrtti = Sāmkhya-Saptati-Vrtti (V1). (1973). Edited by E. A. Solomon. Ahmedabad: Gujarat University (Bibliotheca Indica. New Series. No. 688.).

SVr. Sāmkhyavṛtti = Sāmkhya-Vṛtti (V1) (1973). Edited by E. A. Solomon. Ahmedabad: Gujarat University.

TK. Sāmkhyatattvakaumudī = Sankhyatatwa Koumudi by Bachaspati Misra. (1871). Edited with a Commentary by Taranatha Tarkavachaspati. Calcutta: Sucharu Press.

YD. Yuktidīpikā = Yuktidīpikā. The Most Significant Commentary on the Sämkhyakārikā (1998). Critically edited by Albrecht Wezler and Shujun Motegi (Vol. I). Stuttgart: Franz Steiner Verlag (Alt- und Neu-Indische Studien 44.)

\section{Other Literature}

The Asțāāhyāȳ of Pānini. Vol. II: English Translation of Adhyāyas Two and Three with Sanskrit Text, Transliteration, Word-Boundary, Anuvrtti, Vrtti, Explanatory Notes, Derivational History of Examples, and Indices (2000). Edited and translated by Rama Nath Sharma. New Delhi: Munshiram Manoharlal Publishers Pvt. Ltd.

Brahmasūtrabhāṣya = Complete Works of Śrī Śañkarācārya in the Original Sanskrit. Vol. VII: Brahmasūtra Bhāsya (1983) [Without the name of the editor]. Madras: Samata Books.

Bronkhorst, J. (1996). God's arrival in the Vaiśeșika system. Journal of Indian Philosophy, 24(3), 281294. 
Bṛhadāranyakopanișad = The Principal Upanișads (1953). Edited with Introduction, Text, Translation and Notes by S. Radhakrishnan. London: George Allen \& Unwin Ltd.

Bṛhadāranyakopaniṣadbhāṣya = Upanișadbhāṣyam. Vol. 3: The Bṛhadāranyakopaniṣad With the Bhāṣya of Śrī Śankarācārya Annotated by Śrī Ānandagiri and Adorned by the Dīpikā of Vidyāranya Muni (1986). Edited with Introduction, Notes etc. by Shri S. Subrahmanya Shastri. Varanasi: Mahesh Research Institute (Advaita Grantha Ratna Mañjūṣa. Ratna 28.).

Larson, G. J., \& Bhattacharya, R. S. (1987). Encyclopedia of Indian philosophies, Vol. IV: Sāmkhya: A Dualist Tradition in Indian Philosophy. Delhi: Motilal Banarsidass.

Łucyszyna, O. (2011). Ateizm w Sankhja-sutrach i Sankhja-sutra-wrytti. Przegląd Orientalistyczny, 1-2 (236-237), 31-50.

Matilal, B. K. (1977). Nyāya-Vaiśeșika. Wiesbaden: Otto Harrassowitz (A History of Indian Literature. Edited by J. Gonda. Vol. VI. Fasc. 2.).

Nyāyasūtras, Nyāyabhāṣya, Nyāyavārttika and Nyāyavārttikatātparyațīkā = Nyāyadarśanam: With Vātsyāyana's Bhāṣya, Uddyotakara's Vārttika, Vācaspati Miśra's Tātparyațīkā and Viśvanātha's Vrtti (1936, 1944). Critically edited with notes by Taranatha Nyaya-Tarkatirtha, Amarendramohan Tarkatirtha, and Hemantakumar Tarkatirtha. With an Introduction by Narendra Chandra Vedantatirtha. 2 Vols. Calcutta: Metropolitan Printing \& Publishing House. (Calcutta Sanskrit Series 18, 29.).

Potter, K. H. (Ed.) (1977). Encyclopedia of Indian Philosophies, Vol. II: Indian metaphysics and epistemology: The tradition of Nyāya-Vaiśeșika up to Gangeśa. Princeton, NJ: Princeton University Press.

Potter, K. H. (Ed.) (1981). Encyclopedia of Indian philosophies, Vol. I: Advaita Vedānta up to Śamkara and His Pupils. Princeton, NJ: Princeton University Press.

Rājamārtanḍa = The Yoga Aphorisms of Patañjali with the Commentary of Bhoja Rāja (1883). Edited and translated by Rājendralāla Mitra. Calcutta: The Asiatic Society of Bengal (Bibliotheca Indica. New Series. Nos. 462, 478, 482, and 491-492.).

Śābarabhāṣya = The Aphorisms of the Mīmāmsā by Jaimini with the Commentary of Śavara-Svāmin. Vol. I: Adhyāyas I-VI (1873). Edited by Maheśacandra Nyāyaratna, Ganeśa Press: Calcutta (Bibliotheca Indica. New Series. Nos. 44, 85, 95, 101, 115, 142, 154, 174, and 208.).

Tarkasamgraha and Tarkadīpikā = Tarka-Samgraha of Annambhatta with the Author's Own Dīpikā, and Govardhana's Nyāya-Bodhin̄̄ (1930). Edited with Critical and Explanatory Notes by Yashwant Vasudev Athalye. Together with Introduction and English Translation of the Text by Mahadev Rajaram Bodas. Poona: Bhandarkar Oriental Research Institute (2nd ed.) (Bombay Sanskrit Series. No. LV.).

Tattvavaiśārad̄̄-see below Yogasūtras.

Verpoorten, J.-M. (1987). Mìmāimsā Literature. Wiesbaden: Otto Harrasowitz (A History of Indian Literature. Edited by J. Gonda. Vol. VI. Fasc. 5.).

Yogasūtras, Yogasūtrabhāşya, and Tattvavaiśāradī = Patañjalasūtrāṇi with the Scholium of Vyāsa and the Commentary of Vāchaspati (1892). Edited by Rājārām Shāstrī Bodas. Government Central Book Depôt.: Bombay (Bombay Sanskrit Series. No. XLVI.). 